\title{
The Ideology of the Dual City: The Modernist Ethic in the Corporate Development of Makati City, Metro Manila
}

\author{
MARCO GARRIDO
}

\begin{abstract}
Postcolonial cities are dual cities not just because of global market forces, but also because of ideological currents operating through local real-estate markets - currents inculcated during the colonial period and adapted to the postcolonial one. Following Abidin Kusno, we may speak of the ideological continuity behind globalization in the continuing hold of a modernist ethic, not only on the imagination of planners and builders but on the preferences of elite consumers for exclusive spaces. Most of the scholarly work considering the spatial impact of corporate-led urban development has situated the phenomenon in the 'global' era - to the extent that the spatial patterns resulting from such development appear wholly the outcome of contemporary globalization. The case of Makati City belies this periodization. By examining the development of a corporate master-planned new city in the 1950s rather than the 1990s, we can achieve a better appreciation of the influence of an enduring ideology - a modernist ethic - in shaping the duality of Makati.
\end{abstract}

The most obvious thing in some parts of Greater Manila is that the city is Little America, New York, especially so in the new exurbia of Makati where handsome high-rise buildings, supermarkets, apartment-hotels and shopping centers flourish in a setting that could well be Palm Beach or Beverly Hills. Here the houses look like stage sets for The Great Gatsby and people live lives out of a play by Neil Simon or Edward Albee.

(Metropolitan Manila Commission, 1982)

\section{Introduction}

Global city theory is useful in helping us comprehend the global urban system, but its utility diminishes considerably as an explanation for the predicament of world cities 'beyond the West', in Gugler's phrase (2004). ${ }^{1}$ Indeed, when it comes to explaining segregation in these cities, global city theory is actually misleading in two respects. First,

Gavin Shatkin contributed significantly, both ideas and data, to the development of this article. Jen Green at the University of Michigan's Spatial and Numeric Data Library was instrumental in helping me prepare my maps. Comments from the three IJURR reviewers, all excellent, helped me sharpen my argument.

1 See Part IV of Brenner and Keil (2006) and Robinson (2002) for extended criticisms of global city theory on this point. 
by virtue of its emphasis on globalization it may lead us into confounding spatial polarization with segregation. Global city theory explains the former mainly as a result of occupational polarization brought about by the rise of advanced corporate services. A bifurcated labor market — on one hand a demand for a highly skilled and educated workforce, and on the other for low-skill, low-wage, and often casual workers - distorts the market for urban land and housing and manifests spatially as a 'dual' or 'quartered' city. Duality takes the form of an organized center occupied by global corporate capital and disorganized peripheries fragmented by race, ethnicity, gender, occupation, etc. (Mollenkopf and Castells, 1991; Sassen, 2006). Marcuse (2002) favors the term 'quartered' insofar as cities today seem not only partitioned but 'painfully pulled apart' (ibid.: 270). But, of course, as Marcuse and Van Kempen (2000) have pointed out, world cities have long been segregated and often for different, context-specific reasons, and spatial polarization has tended mainly to strengthen existing patterns of segregation rather than to create new ones ex nihilo. That is to say, globalization explains the current direction of spatial change — towards greater 'inequality and walling' (ibid.: 219) — but not, adequately anyway, the spatial form of world cities.

Second, global city theory is misleading by virtue of its emphasis on the historical experience of cities in the Global North. First, an explanation of spatial polarization on the basis of postindustrial transition - a shift from manufacturing to services - does not apply or does not apply quite in the same way to Southern cities. Some of these cities are experiencing a boom in manufacturing, while others have never had much of a manufacturing sector, and, for that matter, even less of a middle class to be eroded as a consequence of the putative shift. In fact, the middle class has grown in Asian and Latin American cities as a result of globalization (The Economist, 2009). Moreover, polarization as a description of spatial change masks differences across the development divide in spatial forms, the magnitude of certain spatial forms (e.g. slums), and the cultural meaning of similar spatial forms. Consequently, what counts as spatially new for Marcuse and Van Kempen (2000) - the emergence of a quartered city consisting of parallel patterns of residential and business space ${ }^{2}$ - poorly describes the reality of segregation in Southern cities, pace UN Habitat (2003), despite the simple addition of the informal city and the city of illegality.

The dual city, not the quartered city, is the more appropriate metaphor, although I do not mean duality as Mollenkopf and Castells (1991) use it with regard to New York (which, by their own admission, is not really dual anyway). Cities in the Global South have long been dual and never more categorically so than during their colonial period when spatial boundaries were drawn to mark a civilizational divide (King, 1991). While today's spatial boundaries are mainly socioeconomic in provenance, they still carry the connotation of a civilizational inequality, and while the pattern of segregation is more complex, the social distinction between a 'modern' and 'popular' sector ${ }^{3}$ continues to manifest spatially in the division between the planned and 'spontaneous' city (Balbo, 1993). This is a distinction well-grounded in urban reality - slums in Southern cities count for much more than a quarter (of a quartered city) and informal labor far more than a fraction of a class (as a hypothetical 'proto-proletariat') $)^{4}$ - and while finer social and spatial divisions exist, this distinction tends to organize them dichotomously and thus

2 The luxury city and the controlling city, the gentrified city and the city of advanced services, the suburban city and the city of direct production, the tenement city and the city of unskilled work, and the abandoned city and the residual city.

3 Portes (1985) proposes that social classes in Latin America, which he defines mainly by ownership of the means of production, might be grouped into a modern and popular/informal sector. This distinction, of course, recalls the classic elite/masses distinction propounded by the dependistas and postcolonialists.

4 According to UN Habitat (2001), slums comprise $43 \%$ of the urban population in developing regions (78\% in the least developed countries). According to the ILO (2002), informal employment comprises over half of all non-agricultural employment in most developing regions (e.g. 51\% in Latin America, 65\% in Asia, 72\% in Sub-Saharan Africa). 
override them. In other words, for cities in the Global South, the pattern of segregation commonly associated with polarization - urban landscapes fragmented into networks of privatized elite spaces overlaying the public city - has more to do with colonialism than with globalization in its contemporary manifestation.

Postcolonial cities are dual cities not just because of global market forces, but also because of ideological currents operating through local real-estate markets - currents inculcated during the colonial period and adapted to the postcolonial one. Following Kusno (2000), we may speak of the ideological continuity behind globalization in the continuing hold of a modernist ethic, not only on the imagination of planners and builders but on the preferences of elite consumers for exclusive spaces. I say ethic after Gramsci's notion of the 'ethical state' ${ }^{5}$ in order to suggest that an image of modernity represented more than an aesthetic for postcolonial planners and builders but a moral injunction ('make subjects citizens'), indeed, the main content of a civic nationalism (Chatterjee, 2006: 31; also 1994: chapter 10). There is a line of thought in the literature on postcolonial urbanism recognizing the relation between urban development and national identity. Kusno writing on Jakarta, Pinches (1994) and Lico (2003) on Manila under Marcos, and Holston (1989) on Brasilia identify a narrative of progress underwriting the transformation of urban space, mainly through the building of megaprojects and monuments, into a showcase of national modernity. They all make a point to underscore the exclusivity of this identity. The claim to modernity is made against the 'backward' masses, Kusno writes, and modern spaces defined against 'the kampung in the periphery' (2000: 111). Marcos' program of urban modernization explicitly prioritzed the removal, containment and concealment of squatters - perceived as not only culturally unfit for a modern civil society but, indeed, an affront to it. Pinches (1994: 14) describes Imelda Marcos' exertions to blot out the presence of squatters along the itinerary of various foreign dignitaries: US President Ford in 1975, IMF and World Bank conferees the following year, and Pope John Paul II in 1981. The squatters that could not be relocated in time were concealed behind whitewashed fences. This literature has mainly focused on urban projects backed by an authoritarian state. Most of the scholarly work considering the spatial impact of corporate-led urban development has situated the phenomenon in the 'global' era - to the extent that the spatial patterns resulting from such development appear wholly the outcome of contemporary globalization. ${ }^{6}$ The case of Makati City belies this periodization. By examining the development of a corporate master-planned new city in the 1950s rather than the 1990s, we can gain a clearer understanding of the influence of an enduring ideology - a modernist ethic — in shaping the duality of Makati.

Despite inauspicious beginnings as a swampland and seedy 'Sin Town', Makati became the commercial and financial center of the metropolitan region and the nation (see Figure 1). Metro Manila's claim to world city status (considered a Beta plus world city according to GaWC, 2008) is a direct function of Makati's postwar growth. Makati's primacy is sufficient to have caused one student radical in the early 1970s to say that in order to destroy the Philippine economic system, all one had to do was take out Makati (FFI, 1983: 88). With a land area slightly over 4\% of Metro Manila's, Makati boasts $40 \%$ of the top 1,000 corporations in the country, 54 embassies and 35 consulates, and 12 international organizations including the World Health Organization, the United Nations Children's Fund, and the United Nations Development Program (Makati City Portal, 2009). As an ICT hub, the city has the most developed telecommunications infrastructure in the country. According to one study, the quality of life in Makati (calculated using

5 'Every state is ethical in so far as one of its most important functions is to elevate the great mass of the population to a given cultural and moral level, a level or standard which corresponds to the needs of development of the forces of production and hence to the interests of the dominant classes' (Gramsci, 1971 [1929-35]: 246).

6 See Connell (1999), Clammer (2003), Shatkin (2008) and Rimmer and Dick (2009) on Manila; Robins and Aksoy (2000) on Istanbul; Sandhu and Sandhu (2003) on cities across the Global South. 


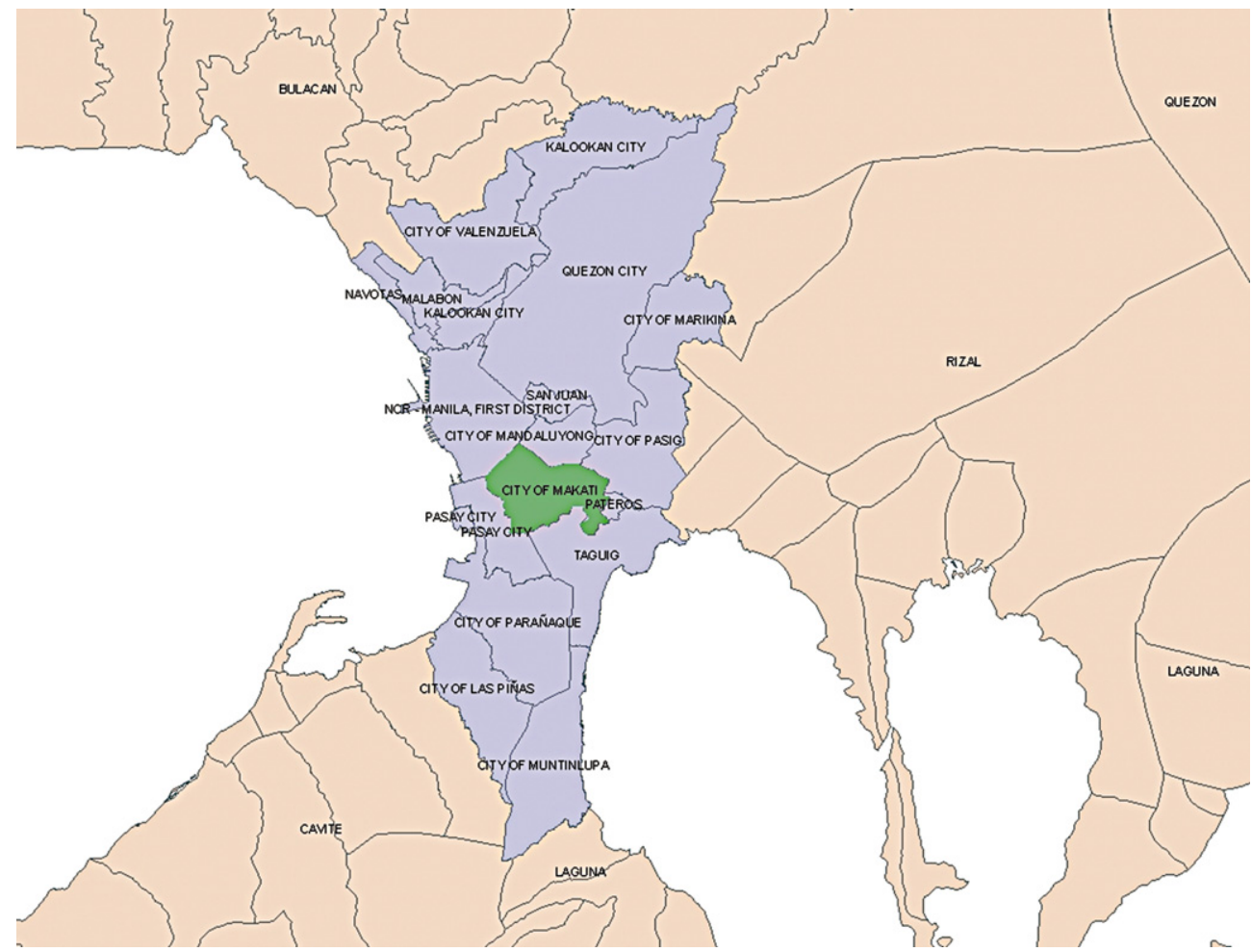

Figure 1 Makati City in Metropolitan Manila (map created by the author)

Table 1 Comparisons between Makati City, New Makati (an enclave within Makati City) and Metro Manila (2000)

\begin{tabular}{lccr} 
& Makati City & New Makati & Metro Manila \\
\hline Population & 471,379 & 36,320 & $9,932,560$ \\
\hline Land area $\left(\right.$ in $\mathrm{km}^{2}$ ) & 27.36 & 10.14 & 636 \\
\hline Average annual family income (2000) & PHP 534,058 & & PHP 300,304 \\
\hline Average annual family expenditure (2000) & PHP 423,023 & & PHP 244,240
\end{tabular}

Source: Makati City Portal (2009) and the National Statistics Office (2000)

Human Development Index criteria) is closer to the quality of life in Japan than it is to the rest of the country's (Binay, 2005: 44). Yet the city is highly polarized both spatially and socially, with economic elites and global functions concentrated in 'New Makati', a privately planned enclave comprising $37 \%$ of the city's land area and less than $8 \%$ of its population (see Table 1).

A modernist ethic informed both the planning of and the demand for New Makati but not in the same way. The development was originally conceived as a self-contained (bundled) and nominally integrated community, with provision for lower middle- to upper-class housing. It was represented by its planners, apparently in earnest, as an attempt towards a solution to the 'problem' of Manila. In this light, by embodying the highest standards of development, New Makati constituted a space of progress. But in a context of virtually categorical class inequality, where the state's regulatory capacity was relatively weak, corporate planning represented a spatial fix for the upper class, a 
way to wall out the disorder of the public city and, at the same time, preserve within its perimeter a standard of spatial order commensurate with its sense of social position as being equal, or more precisely, coeval, with its urban counterparts in the West. It is important to recognize that demand for a New City was premised on an assessment of the existing city by one class, for whom 'disorder' signified more than just unregulated building or jumbled streets but crime, squatting, density, noise, stink, unsanitary conditions and general backwardness - i.e. spaces associated with, and adulterated by, the masses; i.e. backward spaces. The role of ideology, then, was contradictory: demand for New Makati was informed by the class ideology of an elite that apprehended the city in terms of sociospatial and cultural inequality, hence, their impulse to wall in/out, while the imagination of its planners - part of the same elite - was influenced by a modernist ethic that viewed the city in terms of a nationalist project. We must recognize that the contradictory emphases on nationalism and exclusivity were compatible within the terms of a modernist ethic and merely reflected a situation where the discourse of nationalism was articulated by the same elite that took great pains to distinguish themselves from the bulk of the nation. This compatibility soon showed on the ground - to the dismay of New Makati's planners. Given its status as a commodity, New Makati's demonstration effect only whet demand for a piece of it, and land values rose steeply, the more completely it transformed into the opposite of what its planners had avowedly intended, becoming an enclave the perimeter of which marked a class boundary. Keeping in mind that New Makati represented an ideological as well as entrepreneurial gambit helps to explain the vision informing the plan for New Makati and the moral impetus behind the planning, why New Makati was planned according to a standard of development well beyond that of its surroundings, and the planners' inability to foresee its transformation into an exclusionary enclave. It also helps to explain the extent of demand for a space that was both modern and exclusive. In the following sections, I trace the emergence of segregation in Makati historically as a result of corporate planning, I measure and map the current geography of class inequality, and I discuss its repercussions with regard to social and political contention.

\section{The Makati venture}

With the singular exception of the Martial Law period, the most effective directors of Metro Manila's development in the postcolonial era have been private sector actors. Landed families like the Aranetas, Ortigases, Ayalas and Tuazons owned much of the city's real estate, and government planning agencies were rendered ineffectual by the lack of funding and political will $(\mathrm{Ng}, 1981)$. Until the debut of Forbes Park, the subdivision inaugurating the 'new' Makati, in 1949, private sector real-estate development was marked by a lack of planning beyond the scale of a building or block. Many landowners did little more than 'guard the property and collect the rent' (Muijzenberg and Naerssen, 2005: 151); hence, family-owned agricultural estates gave way to poorly planned and densely populated neighborhoods. In the decades preceding the second world war, developers like the Ortigas family and even the Ayalas of Makati constructed low-cost, minimally provisioned subdivisions intending to sell them quickly and cheaply (FFI, 1983: 129-46). Joseph McMicking, the Ayala Company executive regarded as the visionary behind New Makati, characterized these early efforts as the 'salami approach' to real estate development, with land sold 'by the slice' without regard for how each 'slice' affected the value of the remaining property. It was no wonder, then, that the city came to exhibit a motley and haphazard aspect. McMicking wrote (1958: 98) that the lack of planning in Metro Manila "makes possible the existence within a single city block of a sari-sari store [a small general store], a palatial residence, a barongbarong [a squatter's hut], and what is elegantly known as a "motel" [a hideaway for illicit lovers]'. 
New Makati was explicitly designed to negate this reality. It was supposed to be a 'self-contained community' with residential, commercial and industrial districts, and meant to function as a kind of suburban adjunct to Manila but existing, both spatially and socially, at a sanitary remove. Its entrepreneurial ambition was premised on the power of an ideological conceit. The new development would make money by catering to, and helping create, demand for a space that reflected a certain standard of social order. While this demand originated among Manila's elite, the project was represented, unselfconsciously, in civic-nationalist terms. (It is probably no coincidence that planning for New Makati commenced with the acquisition of Philippine independence.) New Makati was considered as much a social as a financial venture (Villamayor, 1973: 14). 'The Ayalas saw in the shambles of overcrowded Manila an opportunity to create a new town', one that was finally 'modern', finally 'rational' in its use of space, and that could serve as both a 'model' for future development (FFI, 1983: 38, 45) and, as McMicking (1958: 25) wrote with regard to Forbes Park, 'an example of what Filipinos can accomplish'. Ayala planned for a socioeconomically diverse community, with separate subdivisions built to accommodate lower-middle to high income residents; it enacted prohibitive building and land use restrictions (protested as excessive at the time); and took pains to regulate lot sizes, amenities, and the width of roads, not purely in order to profit - why such a surplus of consideration otherwise? - but also to create a different kind of social space.

The development of New Makati was in keeping with the Congrès Internationaux d'Architecture Moderne [International Congress of Modern Architecture - CIAM) tradition of modernist planning, where a projected future is based on the negation of existing conditions and plans are drawn up with the intent to 'subvert and then regenerate the surrounding fabric of denatured social life' (Holston, 1999: 160). Historically, such planning ambitions have often combined with a modernist ethic essentially the notion that modernization constituted the categorical imperative of the postcolonial state - to produce perverse results, especially when taken up by an authoritarian state (see Holston, 1989; and Scott, 1999). Imelda Marcos, for example, had planned to build a 'City of Man' on 77 hectares of foreshore land reclaimed from Manila Bay, a New City that would literally concretize Filipino identity in a frenzy of monumental construction - hence her 'edifice complex' (Lico, 2003). Of course, while the Marcoses had embarked upon a developmental adventure underwritten by the state, one more aptly characterized by what James Scott (1999) called 'authoritarian high modernism', ${ }^{7}$ New Makati was fundamentally a private venture and, as such, limited in scale to the area under corporate control (which was still huge) and subject to market forces - factors which, in the end, may have insured its closer relation to reality and thus its relative staying power. What both endeavors share, however, is the impulse to overwrite facts on the ground with new facts in accord with a modernist aesthetic.

The Makati aesthetic proved exceedingly influential as a model of development for Metro Manila. It would seem to have inspired not only Marcos' endeavors to build the City of Man but, quite directly, the series of corporate citadels constructed during the post-Marcos period. But looking beyond New Makati to consider the city as a whole is to see Makati as a dual city and to reveal the modernist vision informing the Makati venture as exclusive in practice. It is to subvert the heroic reading of McMicking and Ayala Land apt to appear in business-school casebooks and which, in fact, does appear in at least one coffee-table book ( $c f$. Duldulao, 1993) by reading the rise of New Makati as the emergence of a segregated city.

7 A high-modernist ideology is 'best conceived as a strong, one might even say muscle-bound, version of the self-confidence about scientific and technical progress, the expansion of production, the growing satisfaction of human needs, the mastery of nature (including human nature), and, above all, the rational design of social order commensurate with the scientific understanding of natural laws' (Scott, 1999: 4). 


\section{The rise of New Makati}

My argument draws mainly from the most comprehensive account of Makati's development, a report published by the research department of the Filipinas Foundation, Incorporated (FFI), in 1983. ${ }^{8}$ Notably, FFI was founded by Joseph McMicking ${ }^{9}$ and his wife, Mercedes Zobel de Ayala, in 1961 to function as the 'socio-cultural development arm' of the Ayala group of companies; in 1990 it was renamed the Ayala Foundation (Ayala Foundation, 2009). While the FFI report (FFI, 1983: 2) tends to characterize Makati's development as a 'metamorphosis', one that 'can almost be rendered in mythical terms', the actual account describes the supersession of one Makati by another. The report distinguishes between an unplanned and planned Makati, a distinction I render here as between an 'Old' Makati and a 'New' Makati. (Makati proper includes a third area, the land once occupied by the Fort Bonifacio military reservation, but since it was not part of Makati when the report was written, the report largely neglects it, as do I.) I narrate the history of Makati in three 'acts': Old Makati (1914-41), the development of New Makati as a planned enterprise (1948-73), and its transformative effects (1973present). The planned area was meant to be transformative simply by virtue of its demonstration effect, but its own meaning was transformed in the context of Metro Manila. Planned as a model community - self-contained and socioeconomically integrated - New Makati became, instead, the prototypical model of exclusivity. There is an element of tragedy in this development that even the FFI report recognizes. It concludes on a note, ruminating on what Makati might have been 'had the original plan been followed' (ibid.: 403) and suggesting, rather vainly, ways to recover its founding conception.

In the early part of the twentieth century, Makati was largely known for licentious entertainment - gambling, prostitution, cockfighting and the popular Santa Ana Cabaret - and, not coincidentally, as a convention site for politicians. It was at this time that Ayala first ventured into real estate development. Between 1924 and 1941, the company constructed twenty low-quality subdivisions. They had small lots, narrow streets, ill defined blocks, inadequate drainage, and neither running water nor electricity. Subdivisions like Olympia (1924), San Andres (1925), Rizal (1934), Bangkal (1939), Pinagkaisahan (1939), Cosmopolitan (1940), and Metropolitan (1940) were designed to sell quickly to the town's lower-middle-class residents, and they did. The second world war interrupted further building, but the demographic shifts that followed presented Ayala with an opportunity for reinvention. The devastation wrought by the American bombing of the Japanese occupiers - $80 \%$ of the buildings in Manila were destroyed, making it the hardest hit Allied city after Warsaw (Steinberg, 1967) — induced Manila's wealthier residents to head towards the city's more developed suburbs in the north and east, in Quezon City, San Juan and Mandaluyong. At the same time, it resulted in a migration of squatters - half a million were displaced and made destitute by the war southwards to Makati. These demographic shifts were compounded by the city's explosive growth - by 58\% between 1939 and 1948 (ibid.: 38) - and the attendant problems of congestion and housing. ${ }^{10}$ The company could have simply designed more of the same type of subdivisions to accommodate this influx, but under the leadership of Joseph McMicking, it embarked upon a venture premised on the audacious idea of changing a third-class municipality without paved roads or basic utilities to one that could attract Manila's rich. McMicking envisioned building an independently functional 'new town' with integrated residential, commercial and industrial districts; with public

8 My historical account also draws from the following sources: McMicking (1958), Villamayor (1973), Community Development Counsellors (1974), Lachica (1984), Goss (1990), and Duldulao (1993).

9 A managing partner in Ayala y Compania and a colonel in the war, McMicking was Filipino by birth, American by citizenship, Scottish by descent, and an Ayala by marriage.

10 This growth was a function of the expansion of American industry in Manila in the years directly preceding the war. 
parks, schools, hospitals and churches — in his words, a 'self-contained community'. Ayala took two years to plan the town and allowed 25 years for its realization.

The 800 hectare estate set to stage these plans was not exactly the 'clean slate' that the FFI report describes (ibid.: 48). The land was more than merely rice paddies and carabao pastures; it was occupied by 500 squatter families. Ayala had to make them go elsewhere before it could persuade the rich to move south. It did so by further developing cheap subdivisions in the old town and offering them to the families at subsidized prices on the condition that they agree not to sell them during the amortization period. It paid families opting out of this deal to leave Makati altogether. With the land cleared, Ayala mobilized its credit lines and sold its properties in Manila to raise capital; it was ready to build.

Ayala built Forbes Park as far from Manila as it could, the gamble being that the success of the subdivision would raise the value of its land in between. From the start, Forbes Park was planned for the very rich; five hundred lots, each an average size of 250 square meters, with 'fully paved full-width roads, underground drainage, a good water system, elaborate landscaping, restrictions on the use of land' (McMicking, 1958: 24), and a golf course so big that it eventually included its own helicopter pad. But perhaps the greatest extravagance was its price: PHP 6 per square meter when the improvements on the land alone cost twice this amount - a move designed to whet demand and reward early buyers 'for their faith' (ibid.). ${ }^{11}$

When Manila's rich proved reluctant, Ayala developed the subdivision even further. It installed a series of streetlights extending beyond it to Buendia and commissioned roaming guard patrols to allay fears of Hukbalahap ambush along the forbidding Highway 54; it built houses for rent in the style of the Spanish-mission homes around Paolo Alto; and the Ayala family itself moved into Forbes Park. Ayala accounts show that John L. Manning, president of the Ford Motor Company, was the first to buy a lot (Lachica, 1984: 153). While only nine other lots were sold that year (1949), 'the trickle later became a flood as word spread that Forbes was the real estate buy of the decade'. Barely a decade later, McMicking (1958: 25) could credibly boast that 'Forbes Park has become a legend and a symbol, it appears in comic strips and in local movies, and it has become a byword in the Philippines for a certain quality of living'.

With Forbes' success, five other 'elite villages' followed: San Lorenzo (1954) was built for middle-income residents, Bel-Air (1957) for middle to high, Urdaneta (1958) for high, Magallanes (1963) for middle and Dasmariñas (1965) for high. ${ }^{12}$ Ayala furnished the infrastructure for its villages - the plumbing, deep wells, drainage, sewage, power lines and roads - and delegated the responsibility for all basic services - garbage collection, street lighting, maintenance, security, etc. — to the respective residents associations. Indeed, the FFI report (1983: 112) estimated that it would take the local government 25 to 30 years simply to raise enough funds to provide village residents the services necessary to maintain 'the minimum standards of a modern and orderly community'. These six elite villages effectively demarcated the perimeter of the 'new town'. The other parts of McMicking's plan were soon implemented: The Kayamanan Industrial district, the Makati Commercial Center ${ }^{13}$ the Ayala Museum and a zone for business administration, with office buildings built around an airstrip that had been transformed into the central business district's main thoroughfare, Ayala Avenue.

Ayala built New Makati in accord with a clear and well-developed vision, and it took pains to preserve that vision by contractually mandating a battery of land use and building regulations designed to guarantee a certain standard of development - a

11 In comparison, land in the richest neighborhoods of Manila at the time went for PHP 90 per square meter (FFI, 1983: 53).

12 Another subdivision - San Miguel (1960) - was also built during this period for lower-middle-income residents and probably not coincidentally located in the vicinity of Old Makati.

13 Like the elite villages, the Makati Commercial Center was maintained not by the city but by a tenants association. 
standard conceived to repudiate the disorder of the built environment in Metro Manila. In Forbes Park, for example, Ayala determined how much one could spend on a house (a minimum of PHP 40,000 in 1954), how large the house could be (no more than $30 \%$ of the lot), what it could be made of (only strong materials), and who could occupy it (a single family) (FFI, 1983: 105-6). In the commercial district, buildings had to be built of reinforced concrete, centrally air-conditioned, serviced by elevators, and at least six stories high; buildings on intersections had to be curved at the corners for greater traffic visibility; no retail stores, restaurants or gas stations were allowed on the ground floors of buildings fronting Ayala Avenue; and, according to Gloria (1995: 84), no beggars were allowed within the center before midnight and no scavengers during the daytime. By the end of the 25 years allotted the McMicking plan, Makati's annual income had gone from PHP 100,000 in 1948 to PHP 47.3 million in 1972 (Community Development Counsellors, 1974: 78), ${ }^{14}$ a tremendous accomplishment for a corporation that had not even been opened to the public at the time (Koike, 1993).

The simple demonstration effect of New Makati galvanized the desire to associate one's enterprise with what Makati had come to represent: the future. As a realization of a modernist ethic, and hence, as a model of spatial and social order, New Makati possessed a certain gravity; space reorganized around it, literally. Circumferential road four (C4), for example, had originally been designed to bypass downtown Manila, but with Makati's centrality, it became the main arterial route to and from its central business district (CBD), and consequently the most heavily utilized road in the metropolis (today known as EDSA or Epifanio de los Santos Avenue) (Corpuz, 2000: 138).

The FFI report (1983) contends that Makati's centrality was unplanned, and its 'over-success', as it is diagnosed, compromised the original vision of Makati as a self-contained community. Indeed, today Makati's population of half a million multiplies nearly eightfold to 3.7 million in the daytime on weekdays (Makati City Portal, 2009). The sheer volume of traffic entering and exiting the city creates such a notorious bottleneck along EDSA that hundreds of thousands of decisions are made around 'Makati traffic' - that is, whether it is worth braving. ${ }^{15}$ The city's workers, white and blue collar alike, account for most of this volume. They must commute because they cannot afford to live in the city. Land values rose so steeply that the demand for residential lots declined, having become prohibitive for middle-income buyers. In 1952, a square meter in Forbes Park cost PHP 6, less than double the minimum wage at the time. By 1979, it cost PHP 1,800, an increase of 967\%. Land values in other elite villages appreciated as rapidly. The price of a square meter in Urdaneta Village went from PHP 30 in 1957 to PHP 1,700 in 1979; in Dasmariñas Village for the same dates, from PHP 95 to PHP 1,750 (FFI, 1983: 397-8). Consequently, the socioeconomic distinctions once made among the various subdivisions of New Makati in order to accommodate a range of the city's workforce collapsed into a single classification, becoming uniformly 'enclaves for the rich and expatriates' (ibid.: 391). Makati went from 'a heterogeneous community with proper representation of the rich, the middle class, and the poor, to one which has a growing higher income group and a declining lower income segment increasingly crowded into a smaller area and moving out to adjacent towns like Taguig and Pateros' (ibid.: 405).

The insatiable demand for commercial real estate transformed the entire planned area. Subdivisions were partly reclassified for commercial use; office buildings proliferated beyond their designated area, and the Kayamanan industrial district yielded to mixed-use facilities. Even Ayala's regulatory regime proved insufficient in checking demand. In Legaspi Village, for instance, buildings were zoned for height (23 meters) but not for their number of floors, so building owners would squeeze in one or two extra floors

14 Makati has only kept growing. By 2008, it had an annual income of over PHP 9 billion.

15 Traffic volume is estimated at 1.4 million during the daytime, exceeding the capacity of the two major roads connecting it to the north (EDSA) and south (South Expressway) of the metropolis by $25 \%$ and $50 \%$ respectively (City Government of Makati, 2004). 
within that limit (ibid.: 383). As New Makati grew increasingly commercial and increasingly exclusive, the more it stood out from the rest of the city, and the perimeter of the six elite villages came to signify a class boundary as well as a threshold between different kinds of social space.

The authors of the FFI report clearly lament this transformation. 'It is not yet too late for Makati to revert back to the self-contained community concept that was originally envisioned by its developers', they write, but 'there appears to be an absence of an internal solution to its problems' (ibid.: 405, 407, emphasis in original). And yet the solution they propose - expanding the planned area into the Fort Bonifacio area - as 'the answer to Makati's problems' (ibid.: 406) is as symptomatic of their faith in modernist planning as it is of an ideological blindness to the object lesson of Makati. Given Makati's inflationary influence, it came to pass, of course, that the area was converted from military to residential and commercial use, and, in fact, was developed by none other than Ayala Land Incorporated. ${ }^{16}$ Bonifacio Global City, as it is now called, is shaping up not into the 'middle and low income residential area' (ibid.: 406) that was supposed to house Makati's workers but into another master-planned, multifunctional citadel rivaling Makati in cosmopolitanism and exclusivity.

\section{Measures of socioeconomic inequality}

To illustrate the extent to which the six elite barangays ${ }^{17}$ comprising New Makati i.e. Forbes Park, Urdaneta, Dasmariñas, Bel-Air, San Lorenzo and Magallanes stand out from the rest of the city, I employ four measures: visible differences, population densities, magnitudes of informal settlement and housing quality. Analytically, we may distinguish New Makati from Old Makati and the Fort Bonifacio area (see Figure 2). Old Makati is where Ayala built low-quality subdivisions before the war. The Fort Bonifacio area in the eastern part of the city was formerly an American military reservation known as Fort McKinley (plus the barangay of Rizal); it was transferred over to the Philippines with independence and renamed. ${ }^{18}$ From an aerial perspective, the area of New Makati is immediately distinguishable (Figure 3). We see that it is greener than its surroundings, that houses are evenly spaced and systematically laid out in defined parcels, and that it is 'well ventilated' by main roads. It is clearly an area that planning has made 'legible' relative to its largely indistinct surroundings. ${ }^{19}$

16 The direct impetus for conversion may have been the coup d'etat attempt against the Aquino administration emerging from rebel soldiers within the camps. It no doubt became apparent that Makati may not be the most appropriate location for a military base.

17 A barangay is an administrative division within cities and municipalities similar to a neighborhood or ward.

18 It should also be noted that a significant portion of the actual Fort Bonifacio compound as it appears on the maps I present (specifically, most of Post Proper Northside and Post Proper Southside) now falls within the jurisdiction of the city of Taguig. A boundary dispute between the two cities erupted when the compound was rendered for conversion from military to commercial and residential use; it was resolved when the Pasig Regional Trial Court upheld Taguig's claim over the whole area in 2003 (Bonifacio Global City, 2009). Unfortunately, my maps were generated using data from the 2000 Philippine Census (NSO, 2000), so they lack the updated spatial configuration.

19 The disparity recalls Pinches' description (1994: 22) of finding his way in a middle class neighborhood through the universal 'language' of bureaucratic order - streets, with names, arranged in a grid - while deciphering the spatial form of poor barangays only 'by coming to know the social form: as particular openings, closures, rises, falls, twists and turns in the spaces between dwellings came to be associated with particular families, households or neighbors'. 


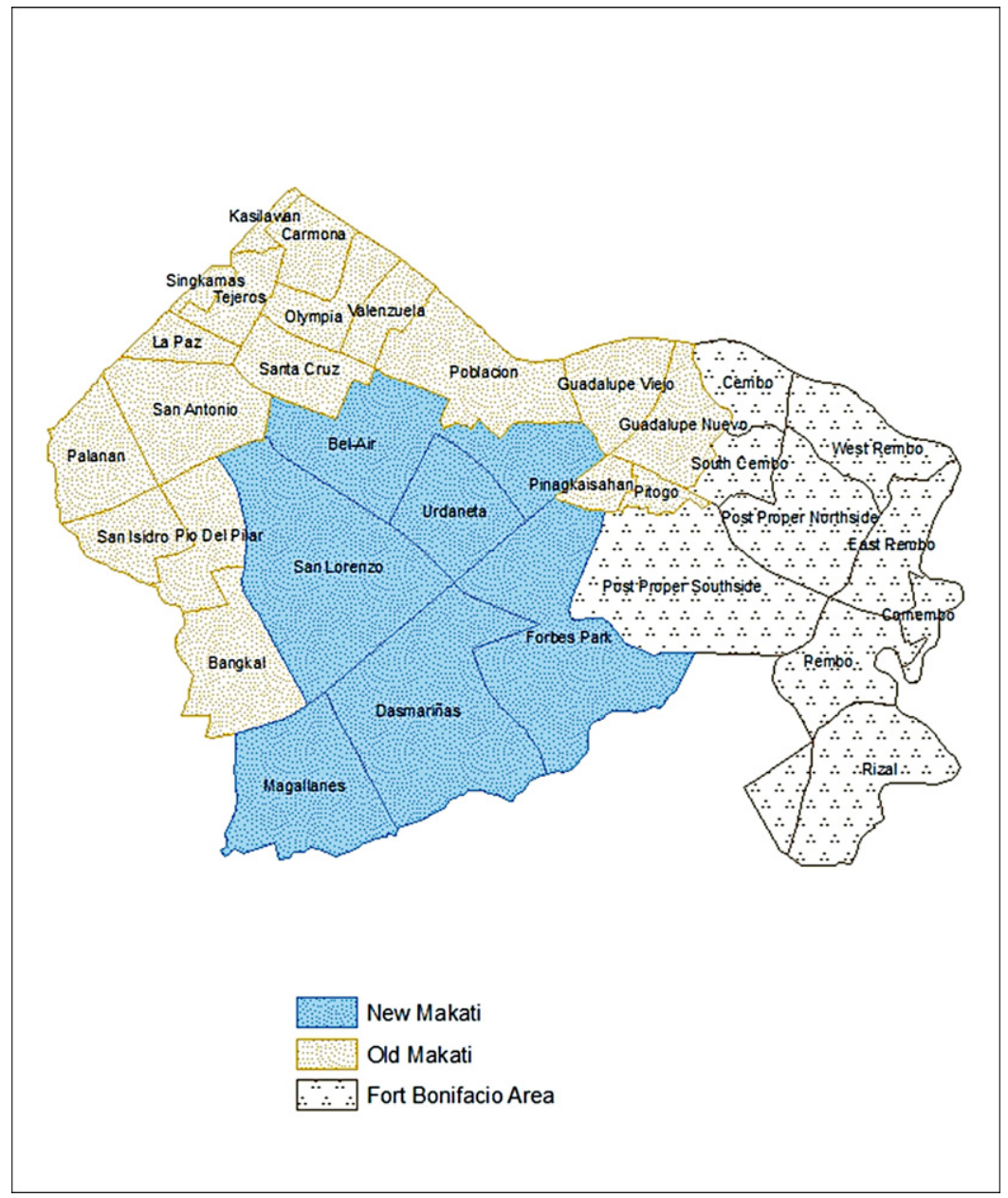

Figure 2 Old Makati, New Makati and the Fort Bonifacio area (map created by the author)

The numbers support what we see. The six elite villages comprising New Makati are the least densely populated of the city's 33 barangays. Altogether, Makati's barangays have an average population density of 349 persons per hectare, but New Makati taken separately has an average population density of only 41 persons per hectare (see Table 2).

The number of informal settlers or squatters within each barangay provides another measure of inequality between the two Makatis (see Figure 4 and Table 3). Informal settlers comprise 10-12\% of Makati's population. While 12,384 families in 2007 accumulated along waterways, railroad tracks and on idle lots, five out of the six elite villages were free of informal settlement (Task Force on Housing and Resettlement, 2007; 2008). The fact that the one village with informal settlers, San Lorenzo, with 241 squatter families, is mainly commercial may explain the exception. But in the context of the city as a whole, these villages are the exception. The barangays just beyond the perimeter of New Makati host significantly greater numbers of informal settlers.

Using 2000 Philippine Census data, I identify three indicators of socioeconomic inequality based on a certain standard of housing: whether the outer walls are made of strong materials (i.e. concrete, brick, stone, glass and asbestos), whether the roof is 


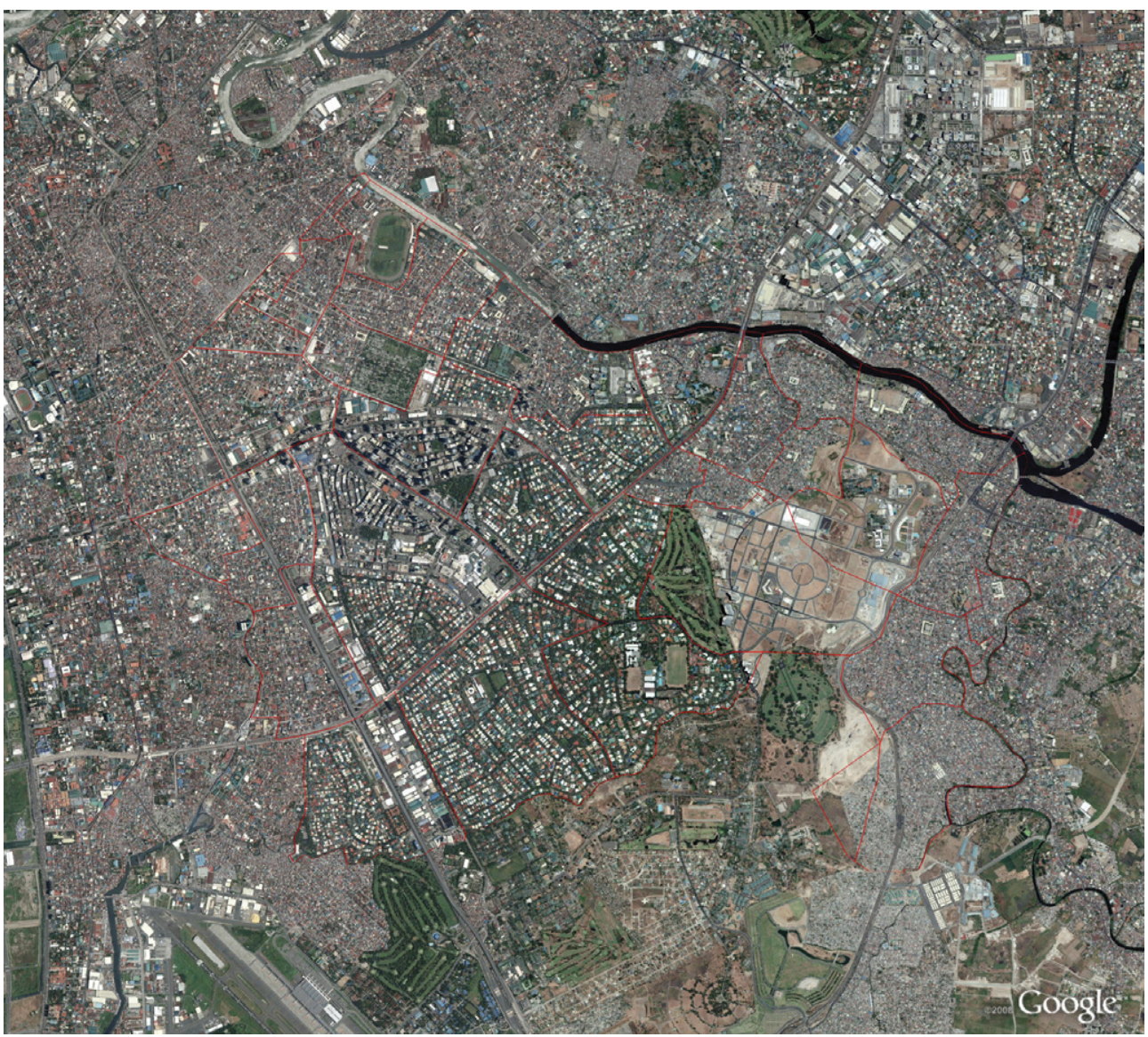

Figure 3 Satellite photo of Makati City (red lines demarcate barangay perimeters) (photo (c) 2008 Google)

Table 2 Average population density in 2000 (persons per hectare)

\begin{tabular}{lc} 
Area & Density \\
\hline Makati & 349 \\
\hline New Makati & 41 \\
\hline Old Makati and Fort Bonifacio Area & 417 \\
\hline
\end{tabular}

Source: Makati City Portal (2009)

made of strong materials (i.e. concrete and clay tile), and whether the floor area is at least 200 square meters. The data show that New Makati observes a housing standard well above the rest of the city (see Table 4). The data from its six villages are so incongruous that if we exclude them the variance among Makati's barangays diminishes considerably. For instance, only $6.7 \%$ of the houses in Makati have a floor area of at least 200 square meters, while $47 \%$ of the houses in New Makati meet this standard. If we remove the six villages of New Makati from the tally, we see that really only $3.1 \%$ of the houses in Makati have the required floor area. 


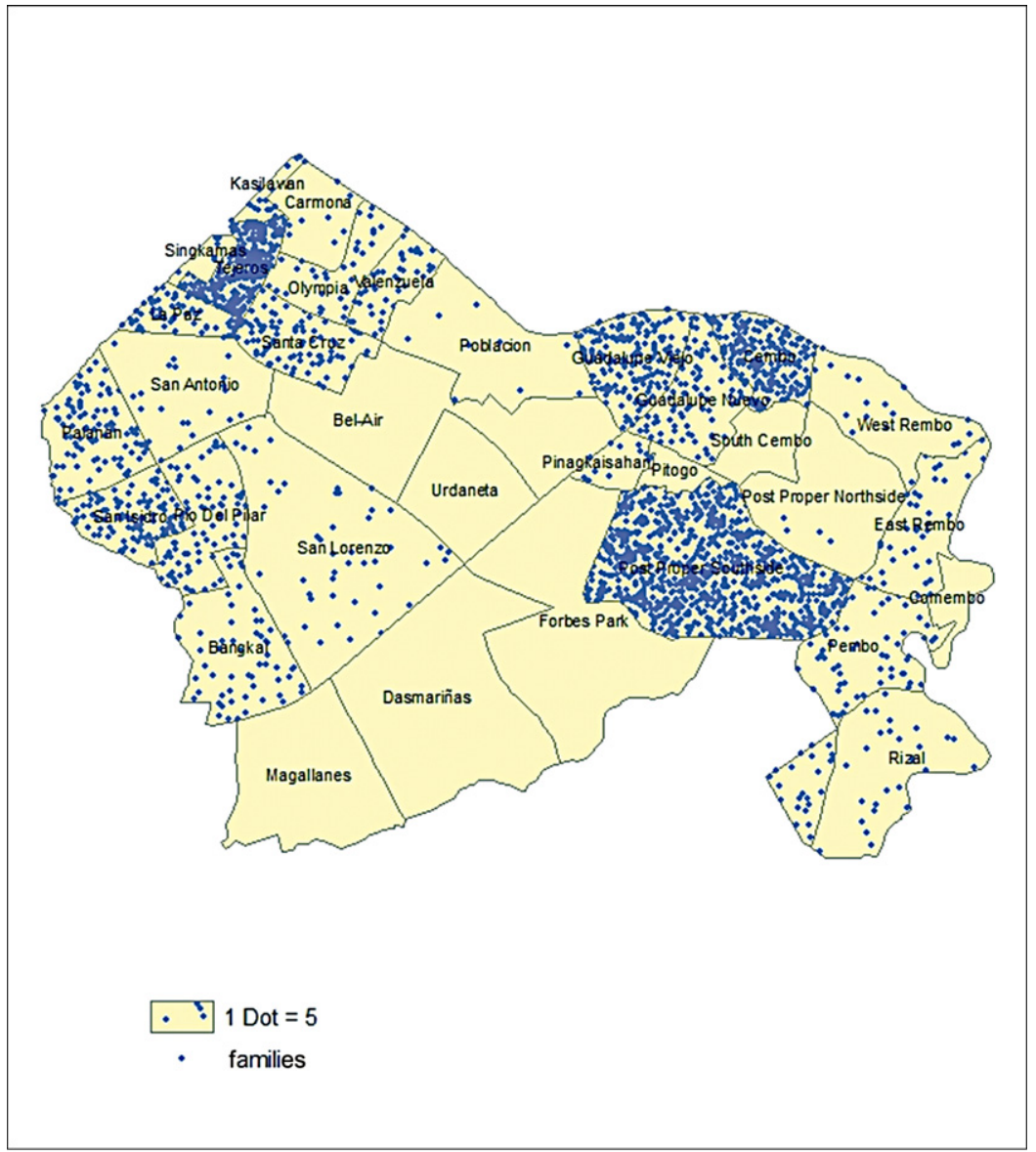

Figure 4 Distribution of informal settlers (map created by the author)

Table 3 Magnitude of informal settlement per area in 2007

\begin{tabular}{lc} 
Area & No. of Families \\
\hline Makati & 12,384 \\
\hline Old Makati & 5,979 \\
\hline Fort Bonifacio Area & 6,164 \\
\hline New Makati* & 241 \\
\hline
\end{tabular}

*All in San Lorenzo

Source: Task Force on Housing and Resettlement (2007)

Next, I scored each barangay by adding the percentages obtaining from each indicator. ${ }^{20}$ As expected, the six elite villages of New Makati ranked first through sixth mostly by large margins, and the average score for New Makati's barangays was more than three times the average score for the rest of the city (Table 5). Figure 5 illustrates the spatial concentration of inequality in housing standards.

20 For example, $89.7 \%$ of the houses in Forbes Park had strong outer walls according to our standard, $12.7 \%$ had strong roofs and $89.9 \%$ had a floor area of or exceeding 200 square meters; totaling all three percentages yields a score of 192 out of a possible maximum score of 300 . 
Table 4 Percentage of houses per area meeting high standards

\begin{tabular}{lccr} 
& Floor area $\%$ & Outer wall \% & Roof \% \\
\hline Makati & 6.7 & 47.0 & 4.5 \\
\hline New Makati & 47.0 & 77.2 & 22.2 \\
\hline Old Makati and Fort Bonifacio & 3.1 & 44.3 & 2.9
\end{tabular}

Source: National Statistics Office (2000)

Table 5 Average housing quality score per area

\begin{tabular}{lc} 
& Housing Quality Score \\
\hline Makati & 70 \\
\hline New Makati & 162 \\
\hline Old Makati and Fort Bonifacio area & 49 \\
\hline Source: National Statistics Office (2000) &
\end{tabular}

\section{Social difference and political contention}

Segregation conveys a sense that different kinds of people occupy different kinds of spaces; it connotes social and spatial difference. New Makati is certainly a different kind of space from the rest of the city. It has no sari-sari stores or palengkes, ${ }^{21}$ only convenience stores and supermarkets; restaurants are more expensive, being subject to the premium of their location; tricycles ferry domestic help to the back door not residents to the front door; checkpoints effect a kind of cordon sanitaire around residential areas; there are more trees and public spaces have not yet been overrun. A resident of one of the poorer areas in Barangay Pio del Pilar may never set foot inside the Greenbelt mall in Ayala Center merely a few kilometers away from where he lives; were he to enter the mall, he may suddenly find himself feeling out of place, even ashamed. ${ }^{22}$ Alternately, a club, bar, café or mall in the commercial district may very well be the place to be seen as the stage for performing one's class aspirations. Just as Cairo's upper middle class flock to up-market coffee shops to pretend that they are no longer in Egypt (Koning, 2003), the lower and middle income classes frequent New Makati to pretend, for the moment, that they belong there. ${ }^{23}$ The point is, for many of Makati's residents, going to New Makati means crossing a social boundary. That is to say, segregation involves more than just the geographical separation of Makati's rich and poor; it would also seem to imply the existence of two distinguishable communities. Moreover, unequal spaces come to be seen as being occupied by unequal kinds of people, often with a symbolic boundary drawn between those with a presumptive right to the city and those thought not to deserve

21 Small general stores usually fronting a residence and wet markets.

22 As Pinches (1988: 179) writes, class boundaries are patrolled from above by acts of shaming, such that 'when people find themselves in the company of others more privileged than themselves, or are faced with this prospect, they commonly say "we feel ashamed" ("nahiya kami" or simply "nakakahiya")'.

23 '[The poor] see the "New Town" as beautiful, clean, and exciting. It is a park or a museum around which to stroll on Sundays. A favorite pastime is "window shopping" in the Commercial Center, sometimes followed by an outrageously expensive merienda... The "treat" is a vicarious experience of the life-style and the daily pleasures afforded the wealthy, and all one needs is small savings from a weekly wage or some additional income; to wear one's Sunday best; and to be prepared to communicate in English' (Goss, 1990: 130). 


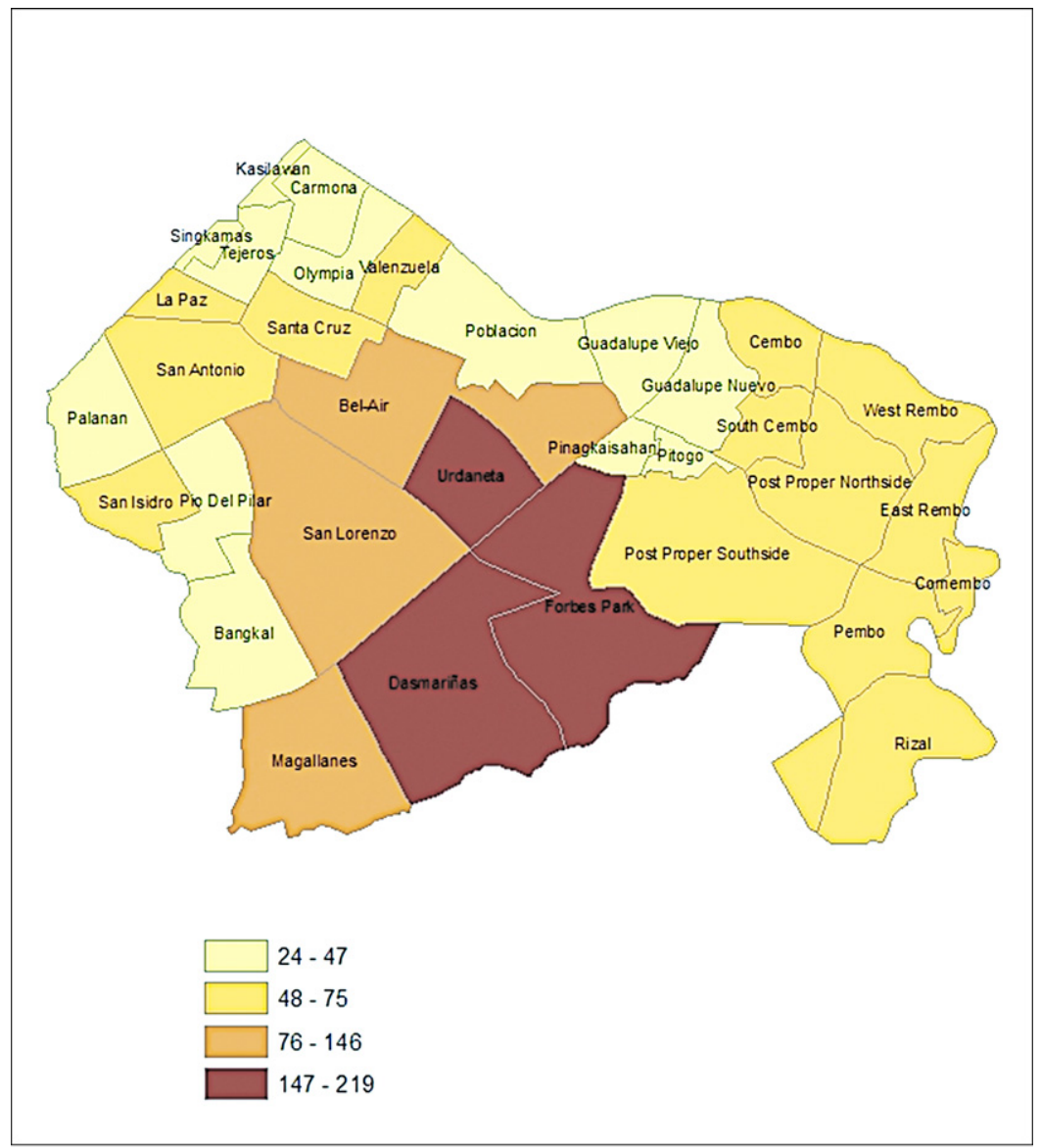

Figure 5 Housing quality scores (map created by the author)

that right according to a particular standard of civic competence. Of course, these terms, as well as the boundary itself, are subject to contestation.

This sense of there being 'one city, two worlds', as the journalist Glenda Gloria (1995) described Makati, has enabled a municipal politics characterized by populism a dynamic exemplified by one figure in particular. Jejomar ('Jojo') Binay has dominated Makati City politics since his appointment by President Corazon Aquino in 1986 until his election as vice-president in $2010 .{ }^{24}$ (The Binays still dominate; Binay's son has taken over the mayoralty and his daughter remains one of the city's congressional representatives.) Born poor in Barangay Culi-Culi (now Pio del Pilar), Binay acquired an extensive education, including a law degree, by dint of sheer resourcefulness. During the Martial Law period, he represented indigent clients, political prisoners and victims of human rights abuses perpetrated by the Marcos regime. His longevity is the result of having reoriented the machinery of Makati politics around his person as its peerless boss, as well as having successfully styled himself the preeminent advocate for the 'other' Makati (see Binay's extensive writings, mainly collected in 1993, 2005, 2006). Gloria (1995: 70) writes that Binay begins 'his day

24 Binay's wife, Elenita, replaced him as mayor for one term, from 1998 to 2001, because he could no longer run given the constitutionally mandated term limit. Once her term elapsed and he was free to run again, he resumed the mayoralty. 
early, jogging along the streets of Makati's poor districts and stopping by carinderias to break bread with jeepney drivers and street workers' and ends it 'with a visit to every funeral site in town'. He has repeatedly contested Ayala's hegemony over Makati in the name of the people: 'In the past, people thought Makati was for the Ayalas, but when I became mayor I told myself, Makati is for the people and the Ayalas are only one part of Makati ... I tell the Ayalas: "The government is mine, business is yours" ' (Binay, cited in Gloria, 1995: 82). Rhetorically at least, he has sought to invert the apparent 'geography of centrality and marginality' such that, in Binay's Makati, it is the rich who are dispensable. 'You [the residents of the elite villages] only comprise five percent of the people here, and when it comes to votes, yours don't matter. We can even do without counting them' (ibid.: 83).

Binay's advocacy extends beyond rhetoric and gesture. In addition to a number of social welfare programs targeted mainly towards the poor, Makati residents enjoy free health care, free education through college, and, for senior citizens, free birthday cakes and free movies anywhere in the city. Consequently, being poor in Makati is better that being poor just about anywhere else in Metro Manila. ${ }^{25}$ Of course, these services are made possible by the tremendous revenue brought in by 'Ayala's Makati', and so, the irony is, provisions for the 'public city' are financed by a virtually private or autonomous city that hardly relies on local government for even the most basic services. This functional division between Makati's two worlds from the point of view of the local politician - one world provides the cash, the other the votes, as Gloria puts it (1995: $68)$ - is not peculiar to Binay's administration. ${ }^{26}$ It is the structural outcome of an electoral system of political competition operating in a social context where class inequality, apart from being severe and spatialized, is distributed in an extremely lopsided but predictable manner, such that the few rich are seen as existing socially and spatially apart from the many poor. Where elections are the poor's revenge against the market, we see a politics premised on a strong sense of class difference, a pro-poor politics in a rich city. At the same time, it may also be argued that, despite its redistributive mandate, a populist politics actually reinforces existing spatial patterns because municipal politicians are invested in maintaining their electoral base in poor communities.

In sum, the different ways we divide up Makati analytically are ways of portraying the many dimensions of a fundamental class distinction: planned/unplanned; New/Old; rich/poor; private/public; Ayala's/Binay's or citizen/not-yet citizen. Spatial distinctions shade into social distinctions as maps of familiarity and belonging mirror maps of geographical separation. Sociospatial distinctions, moreover, virtually describe lines of political contention. We need not even look at the results of the 2010 vice-presidential race to know which of Makati's barangays did not vote for Binay. The actual results (Figure 6) only confirm our suspicions. ${ }^{27}$ Where the rich few and the many poor keep to their own spaces, when venturing beyond them carries with it a quality of transgression, it will come to seem as if they are different beyond the fact of their wealth or poverty, as if their interests are somehow opposed - and, of course, they are. A figure like Binay exploits this sense of social difference for political mileage, but more importantly, his

25 This advocacy, by the way, was the basis of Binay's vice-presidential campaign. He ran on the slogan, 'This is how we are in Makati [cue images of the city's well-off poor]. Wouldn't it be great if the whole country were like this?'. The campaign's resonance indicates that the symbolic power of Makati City is national in scope.

26 Binay's predecessor, Nemesio Yabut, also hailing from a poor background, engaged in a similarly personalistic and populist politics, and, like Binay, routinely faced off with the proprietors of Ayala's Makati. Gloria (1995: 92) writes that the residents of Forbes Park protested Yabut's plan to live in the village. Whether out of a sense of tact or spite, Yabut refrained from moving in and instead built a stable for his horses on the lot he had purchased.

27 The breakdown of the 2010 election results by precinct are available on the Comission on Elections website (www.comelec.gov.ph). 


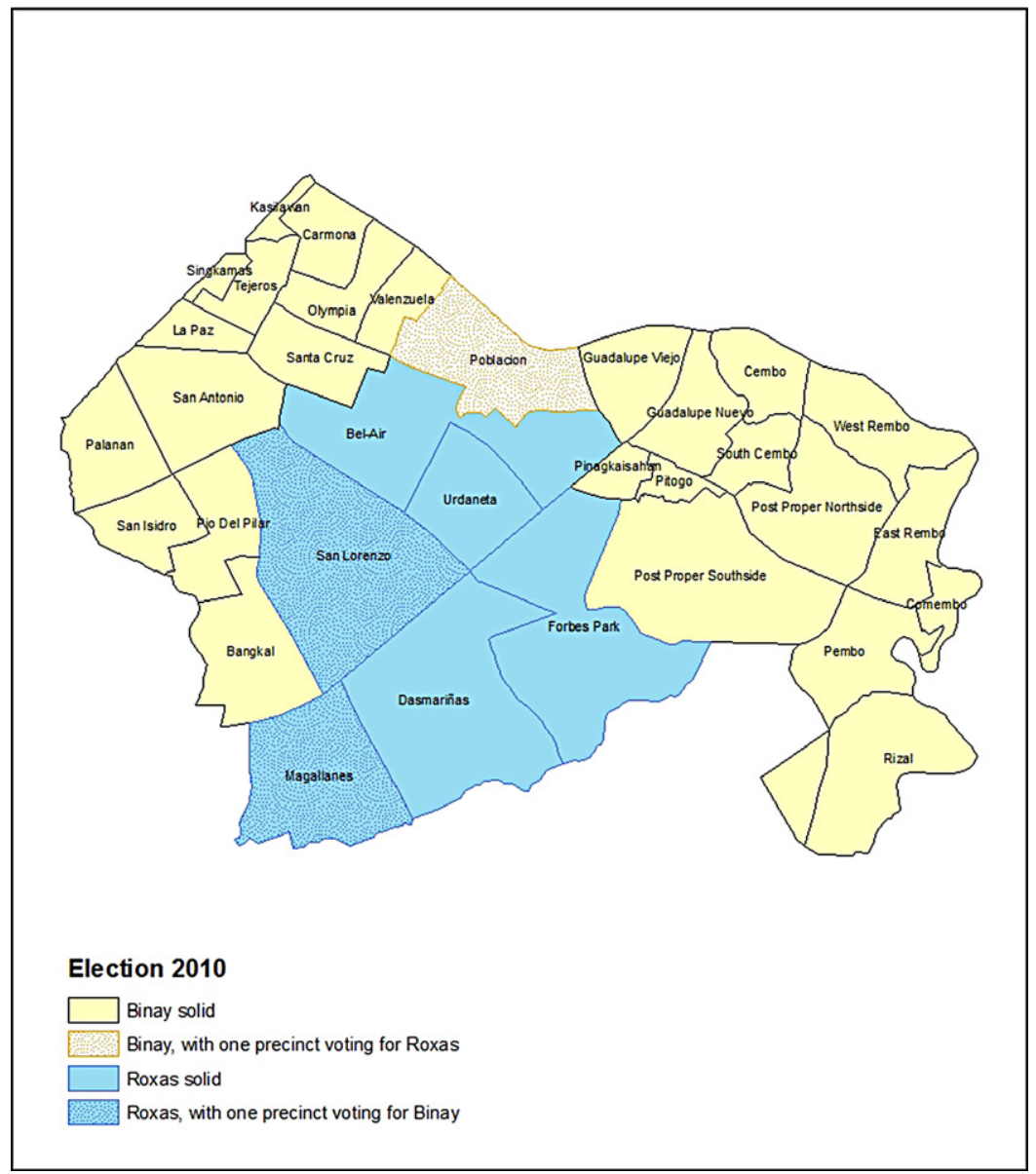

Figure 62010 election results (map created by the author)

rhetoric of class antagonism works because it taps into the everyday grievances of the poor; he succeeds because he is seen as actually representing their claim for an equal right to the city.

\section{Conclusion}

While the segregation of Makati was the result of corporate planning, it was not exactly planned. Certainly, New Makati was good for a class, Manila's elite, for whom the development represented a space commensurate with its sense of social position as a class apart. On the other hand, New Makati was represented as good for the nation, as a space finally commensurate with its modernist longings. This slippage from class to nation - an ideological conceit variously elaborated in terms of hegemony or symbolic domination - functioned to blind planners from the contradictory nature of their enterprise. New Makati's status as a commodity virtually guaranteed its transformation into an elite enclave. How could it not when most of the urban population was not even fully integrated into the formal market? This forgetting of context and history appears to be symptomatic of modernist planning in general, as sufficient cases attest — see Bridge 
and Watson (2002), especially Mabin (2002) and, most notably, Holston's account of Brasilia (1989). ${ }^{28}$

I hope to have conveyed another, more general point as well, that in order to understand the nature of the postcolonial dual city, we need to look behind globalization in its contemporary manifestation and consider the enduring influences of colonialism, in particular how class and ideology, as they shape the city, have been structured by the colonial experience. In the first case, a cultural distinction on the basis of progress ${ }^{29}$ informs elite demands for modern, purified spaces, and in the second, a modernist ethic informs the planning, policy and civic imagination of postcolonial city builders.

It would only be fitting to conclude by recognizing New Makati's own influence as a model of urban development for the metropolitan region. New Makati became the prototype for urban development characterized by a strategy of enclosure: the series of corporate megaprojects bundling services within exclusive spaces and the proliferation of enclaves, walled residential subdivisions called 'villages', throughout the 1990s. ${ }^{30}$ Notably, such developments have largely dispensed with the ambition to somehow model a form of integrated community and are unashamedly being marketed as exclusive (Connell, 1999). Like Makati, they have been developed according to a standard on a par with, if not in many ways exceeding, Western models, a standard aimed at exclusivity. ${ }^{31}$ Their walls literally underline urban inequality. Unlike Makati, however, these corporate developments are emerging within a network of elite spaces, with proliferating citadels (e.g. gated subdivisions, luxury condominiums, high-rise office buildings) linked to spaces of elite consumption (e.g. exclusive malls, recreational areas that are fenced-in or simply forbidding to the poor) through toll-highways and flyovers and equipped with high-technology telecommunications, power and water infrastructures that hardly extend into the public city (Graham, 2000; UN Habitat, 2001; 2003; Sandhu and Sandhu, 2003; Gugler, 2004; Shatkin, 2008). In fact, partially as a result of such high-end building, land values in the city have appreciated to such a degree that virtually the only residential projects currently being undertaken are condominiums and subdivisions for the rich $^{32}$ in the formal sector anyway. Given the dependence of modern lifestyles on the availability of dirt-cheap labor, the parallel growth of informal settlements at the perimeter of villages is continuing apace, ${ }^{33}$ articulating an overall pattern of proximity and walls, such that Metro Manila is rapidly fulfilling the fate augured by the example of Makati City: a dual city where the rich and poor live cheek by jowl but worlds apart.

Marco Garrido (garrido@umich.edu), Department of Sociology, University of Michigan, LSA Building, 500 S. State Street, Ann Arbor, MI 48109-1382, USA.

28 Of course, rather than Brasilianization, Makati was subject to an exclusivization, the result perhaps of having been privately developed.

29 As Pinches (1994: 37) observes, modernity is not simply an ideal but 'a basis for identity-construction as individuals and groups have increasingly come to understand themselves through the degree to which they have achieved progress'.

30 To name a few of the new 'cities': Rockwell, Eastwood, Ayala Alabang, Filinvest Corporate City, etc., with plans for more, notably a CBD in North Edsa being developed by Ayala.

31 For example, when many of its neighboring barangays cannot even rely on a steady supply of water for any purpose, Bonifacio Global City is equipped with a dual piping system that allows one to distinguish between water for drinking, cooking and bathing, and water for flushing, irrigation and outdoor washing (Bonifacio Global City, 2009).

32 The Asian Development Bank (2006) estimates that housing prices in Metro Manila, already the highest among Asian cities, appreciate by an average of $32 \%$ annually. In fact, according to data I have compiled from the Housing and Land Use Regulatory Board, 91\% of all residential construction in the metropolis is for residential condominiums and 'open market' housing (that is, housing whose price is determined entirely by the market, in contrast to socialized housing with price ceilings).

33 The magnitude of informal settlers in Metro Manila is around 43\% (ADB, 2006). 


\section{References}

ADB (2006) Philippines: Metro Manila urban services for the poor, technical assistance consultant's report. Asian Development Bank, Pasig.

Ayala Foundation (2009) History [WWW document]. URL http://www. ayalafoundation.org/history.asp (accessed 25 February 2009).

Balbo, M. (1993) Urban planning and the fragmented city of developing countries. Third World Planning Review 15.1, 23-35.

Binay, J. (1993) Rambotito, basurero, uzisero, atbp [Little Rambo, garbageman, meddler, etc.]. Plaridel Communications Cooperative, Quezon City.

Binay, J. (2005) Governance matters: selected writings and speeches. City Government of Makati, Makati.

Binay, J. (2006) Makati: a city for the people. City Government of Makati, Makati.

Bonifacio Global City (2009) City that works [WWW document]. URL http://www. fbdcorp.com/ (accessed 25 February 2009).

Brenner, N. and R. Keil (2006) The global cities reader. Routledge, London.

Bridge, G. and S. Watson (eds.) (2002) A companion to the city. Blackwell, Oxford.

Chatterjee, P. (1994) The nation and its fragments: colonial and postcolonial histories. Princeton University Press, Princeton, NJ.

Chatterjee, P. (2006) The politics of the governed: reflections on popular politics in most of the world. Columbia University Press, New York.

City Government of Makati (2004) Makati medium term development plan 2000-2004. City Government of Makati.

Clammer, J. (2003) Globalisation, class, consumption and civil society in Southeast Asian cities. Urban Studies 40.2, 403-19.

Community Development Counsellors (1974) Makati report and business encyclopedia. San Juan, Philippines.

Connell, J. (1999) Beyond Manila: walls, malls, and private spaces. Environment and Planning A, 31, 417-39.

Corpuz, A.G. (2000) Integrating transportation and land use planning: the Metro Manila experience. In R. Yabes and C. Chifos (eds.), Southeast Asian urban environments: structured and spontaneous, Program for Southeast Asian Studies, Arizona State University, Tempe.
Duldulao, M.D. (1993) Makati: a vision of tomorrow. Japazzuni Publishing Division, Makati.

FFI (1983) Impacts of the land development in Makati. A report of the research department, Filipinas Foundation, Inc, Makati.

GaWC (2008) The world according to GaWC [WWW document]. Globalization and World Cities. URL http://www.lboro.ac.uk/ gawc/gawcworlds.html (accessed 31 August 2010).

Gloria, G.M. (1995) Makati: one city, two worlds. In J. Lacaba (ed.), Boss: five case studies of local politics in the Philippines, Philippine Center for Investigative Journalism, Pasig.

Goss, J.D. (1990) Production and reproduction among the urban poor of Metro Manila: relations of exploitation and conditions of existence. Unpublished PhD thesis, Department of Geography, University of Kentucky, Lexington.

Graham, S. (2000) Constructing premium network spaces: reflections on infrastructure networks and contemporary urban development. International Journal of Urban and Regional Research 24.1, 183-200.

Gramsci, A. (1971) Selections from the prison notebooks. Edited and translated by Quintin Hoare and Geoffrey Nowell Smith, International Publishers, New York.

Gugler, J. (ed.) (2004) World cities beyond the West: globalization, development, and inequality. Cambridge University Press, Cambridge.

Holston, J. (1989) The modernist city: an anthropological critique of Brasilia. The University of Chicago Press, Chicago.

Holston, J. (1999) Spaces of insurgent citizenship. In J. Holston (ed.), Cities and citizenship, Duke University Press, Durham.

ILO (2002) Women and men in the informal economy: a statistical picture. International Labour Organization, Geneva.

King, A. (1991) Urbanism, colonialism, and the world-economy: cultural and spatial foundations of the world urban system. Routledge, London.

Koike, K. (1993) The Ayala Group during the Aquino period: diversification along with a 
changing ownership and management structure. The Developing Economies 31, 442-64.

Koning, A. (2003) Many degrees of separation: coffee shops and social segregation in Cairo. In R.S. Sandhu and J. Sandhu (eds.), Globalizing cities: inequality and segregation in developing countries, Rawat Publications, Jaipur.

Kusno, A. (2000) Behind the postcolonial: architecture, urban space and political cultures in Indonesia. Routledge, London.

Lachica, E. (1984) Ayala: the Philippines' oldest business house. Filipinas Foundation, Inc, Makati.

Lico, G. (2003) Power, myth, and Marcos state architecture. Ateneo de Manila University Press, Quezon City.

Mabin, A. (2002) Varied legacies of modernism in urban planning. In G. Bridge and S. Watson (eds.), A companion to the city, Blackwell, Oxford.

Makati City Portal (2009) Investing in Makati [WWW document]. URL http://www. makati.gov.ph/portal/index.jsp (accessed 25 February 2009).

Marcuse, P. (2002) Cities in quarters. In G. Bridge and S. Watson (eds.), A companion to the city, Blackwell, Oxford.

Marcuse, P. and R. Van Kempen (eds.) (2000) Globalizing cities: a new spatial order? Blackwell, Malden, MA.

McMicking, J.R. (1958) Makati: an achievement in real estate planning. In $A$ progress report, 1956-1958, Souvenir program on the inauguration of the Makati municipal building, Makati City Hall, Makati.

Metropolitan Manila Commission (1982) A humanist approach to urban management. A report by the Metropolitan Manila Commission.

Mollenkopf, J. and M. Castells (1991) The dual city: restructuring New York. Russell Sage Foundation, New York.

Muijzenberg, O. and T. Naerssen, (2005) Metro Manila: designers or directors of urban development? In P.J.M. Nas (ed.), Directors of urban change in Asia, Routledge, New York.

Ng, K.S.Y. (1981) American influence on planning in the Philippines. Philippine Planning Journal 12.2, 23-34.

NSO (2000) Philippines census 2000 public use file. National Statistics Office, Santa Mesa, Manila.
Pinches, M. (1988) The working class experience of shame, inequality, and people power in Tatalon, Manila. In B.J. Kerkvliet and R.B. Mojares (eds.), From Marcos to Aquino: local perspectives on political transition in the Philippines, Ateneo de Manila University Press, Quezon City.

Pinches, M. (1994) Modernisation and the quest for modernity: architectural form, squatter settlements and the New Society in Manila. In M. Askew and W.S. Logan (eds.), Cultural identity and urban change in Southeast Asia: interpretative essays, Deakin University Press, Geelong, Victoria.

Portes, A. (1985) Latin American class structures: their composition and change during the last decades. Latin American Research Review 20.3, 7-39.

Rimmer, P.J. and H. Dick (2009) The city in Southeast Asia: patterns, process, and policy. University of Hawa'i Press, Honolulu.

Robins, K. and A. Aksoy (2000) Worlds apart and together: trial by space in Istanbul. In G. Bridge and S. Watson (eds.), A companion to the city, Blackwell, Oxford.

Robinson, J. (2002) Global and world cities: a view from off the map. International Journal of Urban and Regional Research 26.3, 531-54.

Sandhu, R.S. and J. Sandhu (eds.) (2003) Globalizing cities: inequality and segregation in developing countries. Rawat Publications, Jaipur.

Sassen, S. (2006) Cities in a world economy. Pine Forge Press, Thousand Oaks, CA.

Scott, J.C. (1999) Seeing like a state: how certain schemes to improve the human condition have failed. Yale University Press, New Haven, CT.

Shatkin, G. (2008) The city and the bottom line: urban megaprojects and the privatization of planning in Southeast Asia. Environment and Planning A 40.2, 383-401.

Steinberg, D.J. (1967) Philippine collaboration in World War II. Solidaridad, Manila.

Task Force on Housing and Resettlement (2007) Magnitude of informal settlers, 2007. Social Welfare Department, City Government of Makati, Makati.

Task Force on Housing and Resettlement (2008) Magnitude of informal settlers, 2008. Social Welfare Department, City Government of Makati, Makati. 
The Economist (2009) The new middle classes in emerging markets. Special report, 12 February.

UN Habitat (2001) Cities in a globalizing world: global report on human settlements 2001. United Nations-Habitat, London.
UN Habitat (2003) The challenge of slums: global report on human settlements 2003. United Nations-Habitat, London.

Villamayor, E. (1973) Development issues on Makati: a maturing new town. Filipinas Foundation, Inc, Makati.

\section{Résumé}

Les grandes villes postcoloniales sont des villes duales, pas seulement à cause des forces de la mondialisation économique, mais aussi à cause de courants idéologiques qui passent par les marchés immobiliers locaux, courants inculqués à l'ère coloniale puis ajustés à la période postcoloniale. Dans le sillage d'Abidin Kusno, on peut signaler la continuité idéologique sous-jacente à la mondialisation, qui s'exerce dans la mainmise pérenne d'une éthique moderniste, non seulement sur l'imagination des urbanistes et constructeurs, mais aussi sur les choix des consommateurs appartenant aux élites qui préfèrent des espaces exclusifs. Les travaux de recherches sur l'impact spatial de l'urbanisation menée par de grandes entreprises ont généralement rattaché le phénomène à l'ère 'mondialisée', dans la mesure où les schémas spatiaux obtenus semblent résulter intégralement de la mondialisation contemporaine. Le cas de Makati dément ce profil temporel. En analysant l'aménagement d'une ville nouvelle selon le schéma directeur d'entreprises dans les années 1950, au lieu des années 1990, on peut mieux apprécier l'influence d'une idéologie persistante - une éthique moderniste dans la configuration de la dualité de Makati. 